\title{
Nucleic acids as indicators of nutritional condition in the Norway lobster Nephrops norvegicus
}

\author{
P. J. Parslow-Williams ${ }^{1}$, R. J. A. Atkinson ${ }^{2}$, A. C. Taylor ${ }^{1, *}$ \\ ${ }^{1}$ Institute of Biomedical \& Life Sciences, Graham Kerr Building, University of Glasgow, Glasgow G12 8QQ, Scotland, \\ United Kingdom \\ ${ }^{2}$ University Marine Biological Station Millport, Isle of Cumbrae KA28 OEG, Scotland, United Kingdom
}

\begin{abstract}
Changes in nucleic acid concentration of the gill, hepatopancreas and abdominal muscle tissue of the Norway lobster Nephrops norvegicus (L.) were examined after 6 and 12 wk of starvation. Significant decreases in RNA concentration, RNA:protein ratio and RNA:DNA ratio were recorded in abdominal muscle tissue following starvation, but not in gill or hepatopancreas tissue. Samples of abdominal muscle tissue were taken from lobsters from 2 sites in the Clyde Sea area, Scotland. These were south of Ailsa Craig, where $N$. norvegicus are thought to be nutritionally limited as a result of the high population densities that occur in this area, and south of Little Cumbrae island, where population density is lower. Evidence of nutritional limitation was provided by nucleic acid analysis which showed that the RNA concentration, RNA:protein ratio and RNA:DNA ratio of lobsters from south of Ailsa Craig were significantly lower than in lobsters of equivalent size from south of Little Cumbrae. Further studies demonstrated that animals from each site were capable of obtaining nucleic acid levels similar to those at the other site after a few weeks when exposed to different feeding regimes.
\end{abstract}

KEY WORDS: Norway lobster $\cdot$ Nephrops $\cdot$ RNA $\cdot$ DNA $\cdot$ Feeding

\section{INTRODUCTION}

Studies of the Norway lobster Nephrops norvegicus have revealed considerable variation in a number of biological parameters such as population density and size-frequency distribution over relatively small geographical ranges, sometimes of just a few kilometres (Cole 1965, Thomas 1965, Chapman 1979, 1980, Bailey \& Chapman 1983, Chapman \& Bailey 1987, Chapman \& Howard 1988, IMBC, UMBSM \& IRPEM 1994, Tuck et al. $1997 \mathrm{a}, \mathrm{b}, \mathrm{c})$. On the basis of these differences, populations of $N$. norvegicus associated with different sediment types are often distinctive enough to be described as separate stocklets (Chapman \& Bailey 1987). In Scottish waters, stocklets occurring on coarse muddy sediments (sandy muds and muddy sands)

\footnotetext{
*Corresponding author. E-mail: a.taylor@bio.gla.ac.uk
}

often consist of individuals characterised by a small average size living at high densities, whereas stocklets found on finer muds tend to occur at lower densities and have a larger mean size. In the Clyde Sea area, the former situation is characteristic of the southern grounds and the latter of the northern grounds (Bailey et al. 1986, Tuck et al. 1997a,b, Field et al. 1998). Benthic faunal biomass appears to be greater on $N$. norvegicus grounds where the silt and clay content is high (Tuck et al. 1997a).

Stocklet differences were originally attributed to variations in fishing pressure (Thomas 1965). It is now believed, however, that they are a consequence of natural differences in the density of Nephrops norvegicus (Chapman \& Bailey 1987, Chapman \& Howard 1988) brought about by the influence of local hydrography on factors such as sediment type and associated organic concentration, and on recruitment of $N$. norvegicus postlarvae (Tuck 1993, Tuck et al. 1997a,b,c). Lobsters 
living at high densities are thought to be subject to high levels of intraspecific competition, resulting in a reduced food intake and consequently a slower growth rate (Bailey \& Chapman 1983, Froglia \& Gramitto 1988, Tuck 1993, Tuck et al. 1997a, IMBC, UMBSM \& IRPEM 1994). The period immediately following postlarval settlement is a crucial phase in the life history of lobsters, since factors affecting survival at this stage can make huge differences to lobster density (reviewed by Cobb \& Wahle 1994).

Estimates of in situ growth rates in Nephrops norvegicus have been improved by incorporating data from tagged individuals (Jensen 1965, Hillis 1979, Bailey \& Chapman 1983), but this approach is hampered by the low rate of recapture (Chapman 1980). Consequently, biochemical indices that provide an indication of condition or that predict the growth rates of lobsters in the field can be extremely useful. RNA concentration and the ratios of RNA:DNA and RNA:protein concentration have frequently been used as indicators of growth rate or nutritional condition in a variety of commercially important fishes (Buckley 1979, 1984, Miglavs \& Jobling 1988, Ferguson \& Danzmann 1990, Mustafa et al. 1991, Foster et al. 1992, Clemmesen 1993, 1994, 1996, Kawakami et al. 1999) and shellfish such as penaeid prawns (Moss 1994a,b, Stuck et al. 1996), lobsters (Juinio et al. 1992, Juinio \& Cobb 1994) and blue crabs (Wang \& Stickle 1986), and also in bivalve molluscs such as scallops (Robbins et al. 1991, Kenchington 1994, Lodeiros et al. 1996) and oysters (Wright \& Hetzel 1985), as well as in cephalopods (Pierce et al. 1999).

The aim of this study was to determine whether RNA concentration, RNA:protein ratio and RNA:DNA ratio could be used as indicators of nutritional condition in the Norway lobster Nephrops norvegicus. Following laboratory calibration, the assays were applied to the 2 contrasting stocklets from the north and south Clyde Sea areas.

\section{METHODS}

Laboratory calibration. Adult Nephrops norvegicus (L.) were collected in September 1996 by trawling on grounds adjacent to the Isle of Cumbrae, Clyde Sea area, Scotland $\left(55^{\circ} 45^{\prime} \mathrm{N}, 04^{\circ} 58^{\prime} \mathrm{W}\right)$. The lobsters were returned to the University of Glasgow, where they were maintained in seawater aquaria at $10^{\circ} \mathrm{C}$. The moult stage of the lobsters was diagnosed by the method of Aiken (1980), and only intermoult individuals were selected since there is evidence that the concentrations of nucleic acids can vary throughout the moult cycle in crustaceans (Humphreys \& Stephenson 1973, Juinio et al. 1992). The study was carried out using only male $N$. norvegicus, since preliminary studies (see below) have shown that there may be significant differences in the RNA concentration of male and female $N$. norvegicus.

In the laboratory, a sample of 30 male lobsters was taken, from which a sub-sample of 10 individuals was frozen immediately in liquid nitrogen and stored at $-70^{\circ} \mathrm{C}$. The remainder were placed individually into plastic tubes $(30 \mathrm{~cm}$ length $\times 10 \mathrm{~cm}$ diameter), the ends of which were covered with a cloth mesh $(5 \mathrm{~mm})$. Keeping Nephrops norvegicus in this way helped to prevent cannibalism, the incidence of which is known to increase during starvation (Sarda \& Valladres 1990). The tubes containing the lobsters were then placed into large plastic tanks with circulating, aerated seawater $\left(34 \%, 10^{\circ} \mathrm{C}\right)$, where they were maintained without feeding under a 12:12 h light:dark cycle. Ten lobsters were removed after periods of 6 and 12 wk of fasting, frozen rapidly in liquid nitrogen, and stored at $-70^{\circ} \mathrm{C}$. Subsequently, samples of abdominal muscle, gill and hepatopancreas tissue were removed from each lobster and analysed for RNA, DNA and protein concentration using the procedures detailed below. All experiments were carried out at the same time of year (November/December), since preliminary experiments had shown that the RNA concentration of the tissues may vary seasonally (Parslow-Williams 1998)

Comparison of 2 stocklets. Adult Nephrops norvegicus were collected in May 1997 by trawling from 2 sites, one from the North Clyde Sea area south of Little Cumbrae $\left(55^{\circ} 41^{\prime} \mathrm{N}, 04^{\circ} 57^{\prime} \mathrm{W}\right)$, and the other from the

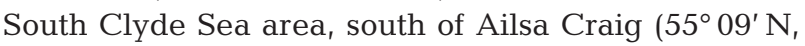
$05^{\circ} 17^{\prime} \mathrm{W}$ ) (Fig. 1). These 2 sites were chosen because they are the locations of 2 stocklets that are markedly different in population characteristics (see above). Samples of 28 lobsters from each site were taken for biochemical analysis. The lobsters were weighed and were then frozen rapidly in liquid nitrogen and stored in a freezer at $-70^{\circ} \mathrm{C}$ prior to analysis. Determinations of the 3 RNA indices were then correlated with fresh body weight for each stocklet.

Diet manipulation experiment. Nephrops norvegicus from south of Ailsa Craig are thought to have access to less food than lobsters from south of Little Cumbrae (Chapman \& Bailey 1987, Tuck et al. 1997a,c). An experiment was designed to investigate the effects of diet manipulation on the RNA concentration of the tissues. During this experiment, lobsters that were captured from the food-limited environment (south of Ailsa Craig) were provided with excess food whereas lobsters from the food-rich site (south of Little Cumbrae) were starved. Forty adult $N$. norvegicus from both the south of Ailsa Craig and south of Little Cumbrae stocklets were transferred to seawater aquaria in a constant-temperature room $\left(10^{\circ} \mathrm{C}\right)$ at the University 
of Glasgow. Lobsters from south of Ailsa Craig were fed ad lib. on a diet of squid mantle, whereas those from south of Little Cumbrae were fasted. Eight individuals from each group were sampled after 0, 6, 12, 24 and $36 \mathrm{~d}$, frozen rapidly in liquid nitrogen and stored at $-70^{\circ} \mathrm{C}$ prior to biochemical analysis.

Biochemical analyses. Nucleic acids were extracted from tissues using a modified Schmidt-Thannhauser method, as detailed by Moss (1994a,b). RNA concentrations were determined using the Orcinol method (Mejbaum 1939). Samples (250 mg) of fresh-frozen tissue were placed into plastic centrifuge tubes to which $4 \mathrm{ml}$ of cold $0.22 \mathrm{~N}$ perchloric acid (PCA) were added. The tissue was broken up using an ultrasonic cell disrupter and then left to stand for 15 min prior to centrifugation $(3000 \times g$ for $15 \mathrm{~min})$. The supernatant was discarded, and the precipitate was washed twice with PCA using the above procedure. Following washing, $4 \mathrm{ml}$ of $0.3 \mathrm{~N}$ $\mathrm{KOH}$ were added to the precipitate and the samples were incubated at $37^{\circ} \mathrm{C}$ for $2 \mathrm{~h}$ to dissolve the precipitate. Standards of Torula yeast (Sigma) were prepared in the same manner. The tubes containing the samples and standards were cooled prior to the addition of $1 \mathrm{ml}$ PCA and further centrifugation.

Finally, $1 \mathrm{ml}$ of the dissolved sample was transferred to test tubes and $2 \mathrm{ml}$ of orcinol reagent added. Following incubation ( $20 \mathrm{~min}$ ) in a boiling water bath, the tubes were cooled and the absorbance values at $665 \mathrm{~nm}$ were determined using a spectrophotometer.

Two methods for the determination of the DNA concentration of the tissues were compared during preliminary experiments. These were a modification of the diphenylamine method (Burton 1956) and the dual wavelength method (Wilder \& Stanley 1983). Samples (50 mg) of tissue and standards (calf thymus DNA, Sigma) were placed in centrifuge tubes to which $5 \mathrm{ml}$ of $0.5 \mathrm{~N}$ PCA were added and the tubes were heated at $70^{\circ} \mathrm{C}$ for $30 \mathrm{~min}$. After cooling and centrifugation $(3000 \times g, 15 \mathrm{~min})$, the absorbance of the samples at wavelengths of 232 and $260 \mathrm{~nm}$ was measured. For the diphenylamine method, $1 \mathrm{ml}$ of the samples or of the standards was then pipetted into test tubes containing $2 \mathrm{ml}$ diphenylamine reagent. The tubes were sealed and incubated at room temperature for $20 \mathrm{~h}$ and the absorbance values at $660 \mathrm{~nm}$ were determined.

Protein concentration was determined on $10 \mathrm{mg}$ freeze-dried tissue samples using a commercially produced kit (Pierce) based on a modification of the technique of Lowry et al. (1951). Data were tested for normality using the Anderson-Darling test, and for

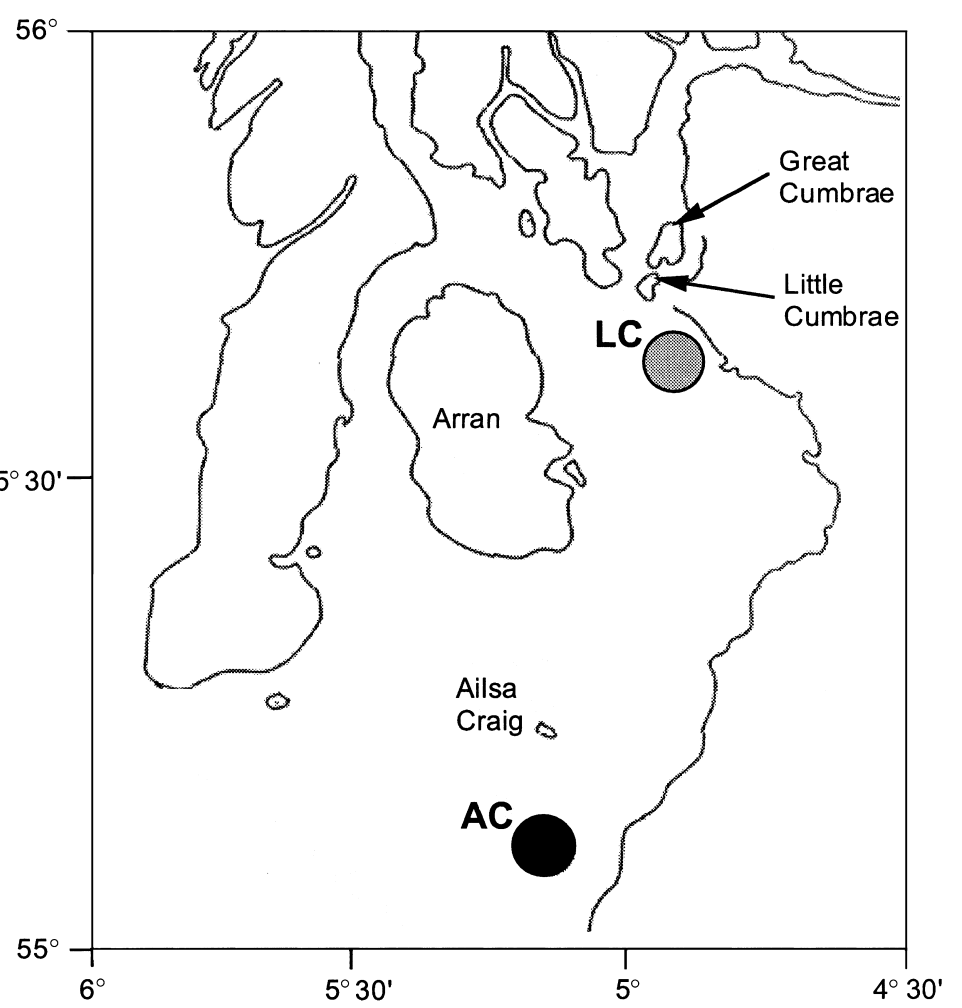

ig. 1. Map of the Clyde Sea area showing Nephrops norvegicus samling sites LC (south of Little Cumbrae) and AC (south of Ailsa Craig)

homogeneity of variances using Bartlett's test. Analyses of parametric data were made by 1-way analysis of variance (ANOVA) coupled with Tukey's pairwise comparison.

\section{RESULTS}

\section{Comparison of the methods for DNA determination}

Replicate samples $(\mathrm{n}=5)$ of abdominal muscle from a single Nephrops norvegicus were analysed using the 2 procedures described above. The mean value for the DNA concentration of the muscle obtained using the diphenylamine method $\left(0.205 \mu \mathrm{g} \mathrm{mg}^{-1} \pm 0.014 \mathrm{SD}\right)$ was not significantly different (Student's $t$-test, $\mathrm{p}>0.05$ ) from that obtained using the 2-wavelength method $\left(0.223 \mu \mathrm{g} \mathrm{mg}^{-1} \pm 0.105 \mathrm{SD}\right)$. Although the 2-wavelength method was quicker and easier to use, the SD values were much greater. The greater accuracy of the diphenylamine method made it the method of choice for all subsequent analyses. Further preliminary experiments (data not shown) demonstrated that the RNA and DNA concentration of the tissues did not change after being frozen $\left(-70^{\circ} \mathrm{C}\right)$ for $4 \mathrm{wk}$. In addition, no significant differences were recorded in either the RNA or 

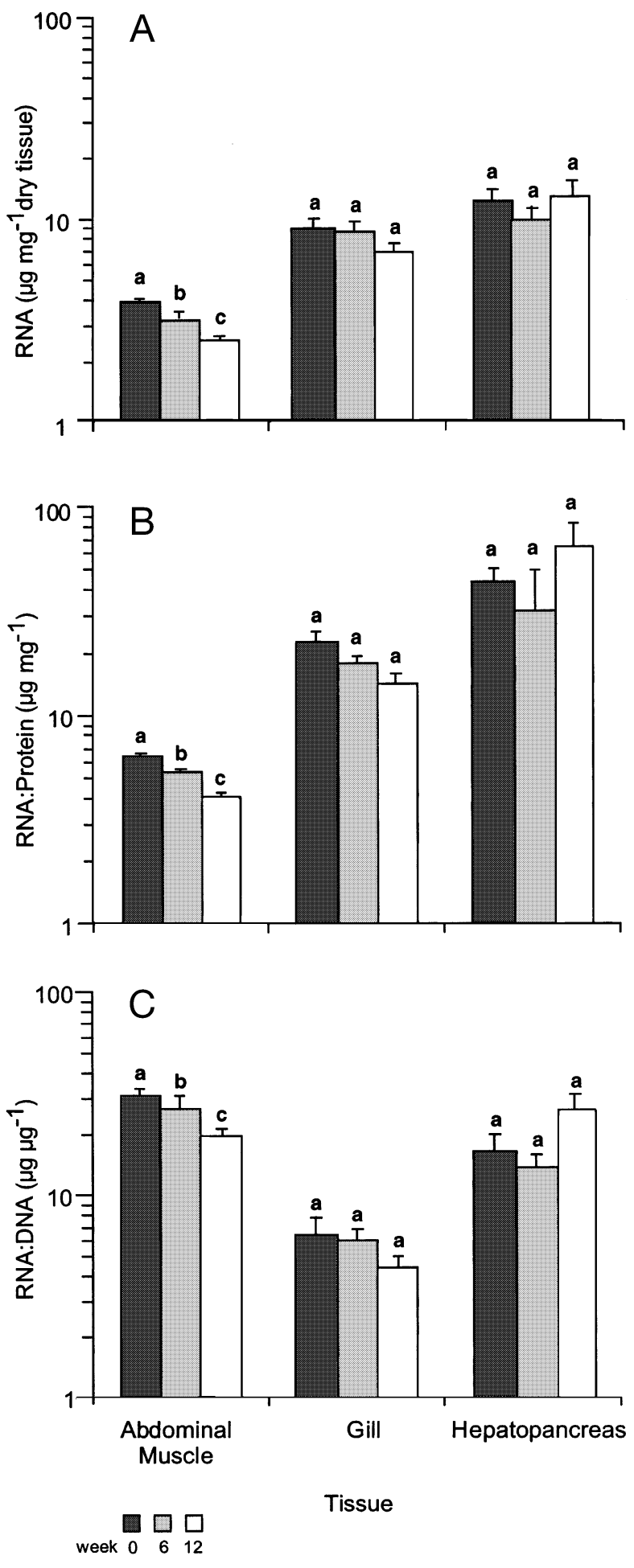

Fig. 2. Nephrops norvegicus. Changes in (A) concentrations of RNA, (B) RNA:protein ratio and (C) RNA:DNA ratio of abdominal muscle, gill tissue and hepatopancreas tissue of lobsters from the Little Cumbrae site following starvation. Data are shown for lobster after 6 and $12 \mathrm{wk}$ of starvation and for lobsters fed throughout this period. Standard errors bars $(n=10)$ are shown. For each tissue, categories sharing the same letter are not significantly different
DNA concentration when the analyses were carried out on either fresh or freeze-dried tissue (following correction for water content).

\section{Laboratory calibration}

A preliminary analysis of the RNA concentration in the abdominal muscle of Nephrops norvegicus from the site south of Little Cumbrae showed that although there was no significant difference in the total fresh weight of the male and female lobsters in the sample analysed (mean weight of females $=17.37 \pm 1.19 \mathrm{~g}$ [SE], mean weight of males $=18.91 \pm 1.03 \mathrm{~g}[\mathrm{SE}]_{;} t=$ $0.98, \mathrm{p}>0.01, \mathrm{n}=17$ ), the RNA concentration in the muscle of male $N$. norvegicus was significantly greater than that of females (mean RNA concentration in females $=3.60 \pm 0.19[\mathrm{SE}]$ and in males $=4.46 \pm 0.18$ [SE] $\left(\mu \mathrm{g} \mathrm{mg}^{-1}\right.$ dry wt); $t=3.98, \mathrm{p}<0.01, \mathrm{n}=17$ ). As a result, only male $N$. norvegicus were used in the rest of these studies.

One-way ANOVAs applied to the data relating to the nucleic acid concentrations of each tissue type (Fig. 2) indicated that, for abdominal muscle tissue, the RNA concentration and RNA:protein ratio decreased significantly $(p<0.05)$ after 6 wk of fasting. Similarly, there was another significant $(p<0.01)$ decrease after a further $12 \mathrm{wk}$ of fasting compared to control individuals that were fed throughout this period. The RNA:DNA ratio of abdominal muscle tissue was not significantly different from the initial ratio after $6 \mathrm{wk}$, but was significantly different $(\mathrm{p}<0.05)$ after $12 \mathrm{wk}$. There were no significant differences $(p>0.05)$ in RNA concentration, RNA:protein or RNA:DNA ratios in hepatopancreas or gill tissue after 6 or 12 wk of fasting. Therefore, only abdominal muscle tissue was used in further analyses.

\section{Comparison of 2 stocklets}

The relationships between nucleic acid concentrations of the abdominal muscle and body weight and between RNA:protein and RNA:DNA ratios and body weight were compared between samples of Nephrops norvegicus from both sites (Fig. 3). There was a significant correlation between RNA concentration and body weight for $N$. norvegicus from the Little Cumbrae $(\mathrm{r}=0.50, \mathrm{p}<0.05)$ and Ailsa Craig $(\mathrm{r}=0.39, \mathrm{p}<0.05)$ populations, and also between RNA:DNA ratio and body weight for individuals from the Little Cumbrae site $(\mathrm{r}=0.40, \mathrm{p}<0.05)$ but not for individuals from the Ailsa Craig site $(r=0.26, p>0.05)$ (Table 1$)$. Although apparently similar negative relationships were found between RNA:protein ratio and body weight for lob- 
sters from both sites, these relationships were not significant $(p>0.05)$. The relationships between nucleic acid concentrations and body weight for lobsters from the 2 sites were compared using analysis of covariance (ANCOVA). This analysis indicated that there were no significant differences $(p>0.05)$ in the slopes of the regression lines fitted to these data, but there were significant differences in the elevations of the regression lines. This confirms that lobsters from south of Little Cumbrae had significantly higher RNA concentrations (ANCOVA $\mathrm{p}<0.001$ ) than lobsters of equivalent weight from the population from the south of Ailsa Craig.

\section{Diet manipulation experiment}

The changes in the weight-specific RNA concentrations, the RNA:protein ratio and RNA:DNA ratio throughout the diet manipulation experiments are shown in Fig 4. Values for each of these parameters increased progressively throughout the experiment for lobsters from the Ailsa Craig site, but showed a progressive decrease among lobsters from the Little Cumbrae site. Comparisons of these parameters between individuals from the 2 sites were made at each of the sampling times (Student's $t$-tests). At the beginning of the experiment, RNA concentration $(p<0.01)$, RNA: protein $(p<0.05)$ and RNA:DNA $(p<0.05)$ were all significantly higher for lobsters from the Little Cumbrae site. At Day 6, RNA concentration and RNA:protein ratios were significantly higher $(p<0.05)$ for lobsters from the Little Cumbrae site, and at Days 12 and 24 there were no significant differences in nucleic acid concentration between individuals from the 2 sites. At the end of the experiment (Day 36), the RNA concentration, RNA:protein ratio and RNA:DNA ratio were significantly higher $(p<0.05)$ for lobsters from the Ailsa Craig site.

Table 1. Nephrops norvegicus. Regression coefficients for equations describing the relationships between RNA concentration, RNA:protein and RNA:DNA ratio and fresh weight shown in Fig. 3. Equations are in form $Y=a X^{b}$. Values for the correlation coefficient $r$ are also given. LC: Little Cumbrae; AC: Ailsa Craig sites

\begin{tabular}{lcrcc|}
\hline & Site & \multicolumn{1}{c}{$a$} & $b$ & $\mathrm{r}$ \\
\hline RNA $\left(\mu \mathrm{g} \mathrm{mg}^{-1}\right)$ & $\mathrm{LC}$ & 9.38 & -0.27 & 0.50 \\
& $\mathrm{AC}$ & 6.35 & -0.26 & 0.39 \\
RNA:protein & LC & 11.48 & -0.21 & 0.26 \\
$\left.(\mu \mathrm{g} \mathrm{mg})^{-1}\right)$ & $\mathrm{AC}$ & 7.21 & -0.17 & 0.19 \\
RNA:DNA & LC & 10.96 & -0.40 & 0.40 \\
$\left(\mu \mathrm{g} \mu \mathrm{g}^{-1}\right)$ & $\mathrm{AC}$ & 7.21 & -0.29 & 0.26 \\
\hline
\end{tabular}
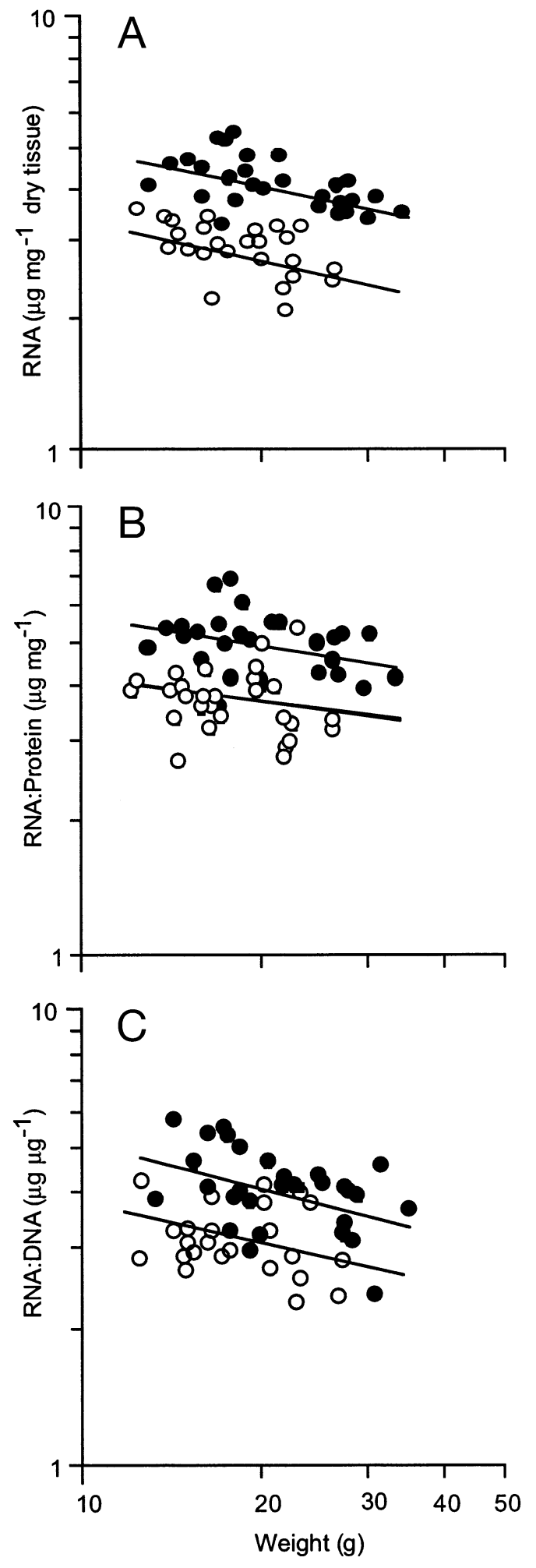

Fig. 3. Nephrops norvegicus. Relationships between (A) concentration of RNA, (B) RNA:protein ratio and (C) RNA:DNA ratio of abdominal muscle and fresh body weight in lobsters from south of Little Cumbrae ( ) and south of Ailsa Craig (O) in the Clyde Sea area. Lines fitted to data are the calculated regression lines 

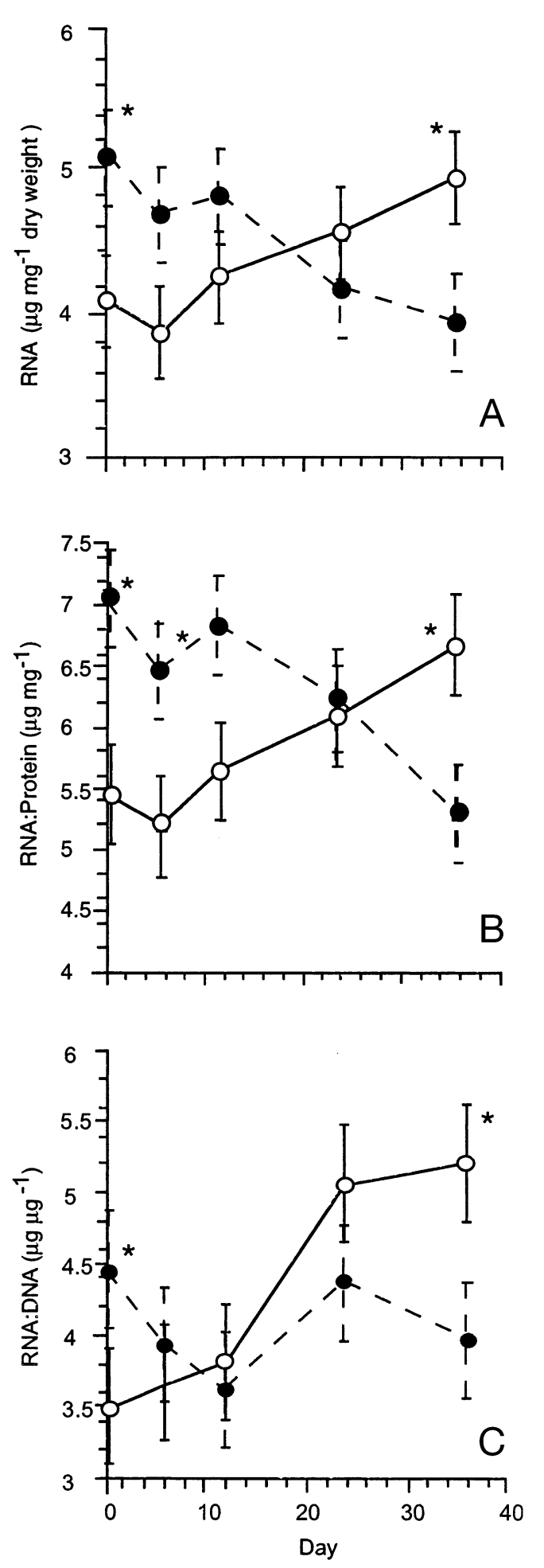

Fig. 4. Nephrops norvegicus. Changes in (A) RNA concentration, (B) RNA:protein ratio and (C) RNA:DNA ratio of abdominal muscle. Lobsters from south of Little Cumbrae ( $)$ were starved throughout this period, whereas lobsters from south of Ailsa Craig $(O)$ were fed to excess. Values are means $\pm \mathrm{SE}$. * Differences between individuals from the 2 sites were significant $(\mathrm{p}<0.05)$

\section{DISCUSSION}

Previous attempts to investigate Nephrops norvegicus from different stocklets for possible differences in nutritional condition have met with limited success. Tuck et al. (1997c) found that $N$. norvegicus from stocklets characterised by slow-growing individuals tended to have lower concentrations of protein, glycogen and lipid in their tissues. No significant differences were observed, however, in the concentrations of their haemocyanin which, in studies of lobsters, have been shown to be correlated with nutritional status (Hagerman 1983).

The results of this study have shown that RNA concentration is a sensitive indicator of nutritional condition in Nephrops norvegicus. The RNA index was found to be most sensitive when concentration was expressed per unit dry weight rather than as the RNA:DNA or RNA:protein ratios. These findings agree with those of a number of workers who recorded increased variability when RNA was expressed as a ratio in both fish (Wilder \& Stanley 1983, Ferguson \& Danzmann 1990) and crustaceans (Moss 1994a,b). Similarly, Houlihan et al. (1998) found that in the cephalopod Eledone cirrhosa the RNA concentration per unit fresh weight showed a higher correlation with growth rate than the RNA:protein ratio. Pierce et al. (1999), in their study of cephalopods, also discussed whether RNA concentration should be expressed in relation to body weight or as a ratio with the DNA or protein concentration. Which index is most appropriate will depend on the extent to which the different variables co-vary and on whether they are affected by processes other than growth.

In many previous studies, the RNA:DNA ratio has been the preferred method of expressing RNA concentration, since it is thought to correct for cell number. However, various problems have been found. For example, DNA concentration has been shown to exhibit a negative relationship with protein synthesis when different tissues are compared (Houlihan 1991, Foster et al. 1992). In the present study, abdominal muscle was the most suitable tissue for nucleic acid analysis, which is appropriate since it is also the portion marketed for human consumption. Other studies have also recommended white muscle for this type of analysis, since RNA concentration in this tissue has been found to be proportional to whole body growth in both fish (Bulow 1987) and in crustaceans (Moss 1994a).

Since Nephrops norvegicus supports the most valuable invertebrate fishery in the United Kingdom, an understanding of the factors contributing to stocklet heterogeneity is of considerable interest. The differences between the stocklets are not thought to have a 
genetic basis, since larvae produced by the different stocklets are able to mix in the water column (Tuck 1993). Furthermore, there appear to be no genetic differences between stocklets in the Clyde; in fact, the genetic variability within stocklets was found to be greater than between Scottish and Mediterranean $N$. norvegicus (Passamonti et al. 1997). The present study has shown significant differences in RNA-based indices between the north and south Clyde stocklets, implying that the differences in the biological characteristics of $N$. norvegicus stocklets are due to environmental factors such as food availability.

Concentrations of RNA in ectothermic organisms may be influenced by temperature. RNA concentration has been shown to change when organisms are acclimated to different temperatures (Goolish et al. 1984, Foster et al. 1992, Juinio et al. 1992), possibly as a compensation mechanism for the difference in RNA activity associated with the new temperature. However, for the 2 stocklets examined in this study, temperature is unlikely to be responsible for the difference in nucleic acid concentrations, since there is very little difference in temperature between the 2 sites throughout the year (IMBC, UMBSM \& IRPEM 1994). It is likely, therefore, that the significant differences in nucleic acid concentration primarily reflect differences in nutrition. Evidence to support this suggestion was provided by the diet manipulation experiments. These demonstrated that, when lobsters from either site were maintained for a few weeks under appropriate feeding conditions, the concentrations of nucleic acids in the abdominal muscle of individuals from a given site gradually became similar to those of individuals from the other site.

Stomach-content analyses have shown that Nephrops norvegicus from both sites in the Clyde Sea area feed on a wide range of invertebrates (ParslowWilliams 1998). Of the material that could be identified, the greatest proportion consisted of small crustaceans (e.g. thalassinidean decapods and small crabs), with significant amounts of echinoderms (mainly brittle stars) as well as bivalve molluscs and polychaete worms. The proportion of bivalve molluscs was higher in the diet of Nephrops norvegicus from the site south of Little Cumbrae than in the diet of individuals from the Ailsa Craig site, which contained larger proportions of echinoderms. This appears to reflect the faunal composition of the 2 areas, since the site south of Little Cumbrae is dominated by bivalve molluscs, whereas other prey such as crustaceans, echinoderms and polychaetes form a greater part of the faunal composition of grounds around Ailsa Craig (IMBC, UMBSM \& IRPEM 1994). These observations agree with those of other studies, which suggest that $N$. norvegicus is principally an opportunistic predator and scavenger (Thomas \& Davidson 1962, Oakley 1981, Bailey et al. 1986, Cristo 1998).

At high population densities, increased intraspecific competition for food may limit growth, especially where high densities occur on sediments with a low organic content and correspondingly low biomass of prey items (Chapman \& Bailey 1987, Chapman \& Howard 1988). Organic carbon levels at the Ailsa Craig site are lower than at the Little Cumbrae site (IMBC, UMBSM \& IRPEM 1994). Lobsters living at high densities could also be subject to frequent aggressive interaction with conspecifics, leading to them spending longer at elevated metabolic levels (Li \& Brockesen 1977) and with reduced time for feeding. Experimental work on the American lobster Homarus americanus (Cobb et al. 1982) demonstrated a reduced moulting frequency in some individuals after the establishment of a dominance hierarchy, even when sufficient food was made available.

It is well documented that significant biochemical changes occur during the moult cycle of Crustacea (reviewed by Chang 1995). However, recent investigations on decapods have found no influence of moult stage on the nucleic acid concentrations of whitemuscle tissue from either the abdomen (Moss 1994a, El Haj et al. 1996, El Haj \& Whiteley 1997) or the legs (including claws) (El Haj et al. 1996). El Haj et al. (1996) did record an increase in protein synthesis during pre-moult, but suggested that an increase in ribosomal activity, rather than RNA concentration, was responsible. Such evidence suggests that, although RNA-based indices provide a good indication of nutritional condition in crustaceans, underlying changes in RNA activity may also occur. Greater precision in defining changes in nutritional status may be obtained by combining this technique with analyses of other indicators of biochemical condition (see Tuck et al. 1997a).

As well as density-dependent effects, populations of Nephrops norvegicus are also subject to a variety of environmental stresses including trawling pressure, prolonged exposure to hypoxia (Hagerman \& Baden 1988, Baden et al. 1994) and parasitic infection (Field et al. 1992, 1995, Field \& Appleton 1995, Taylor et al. 1996). Convenient methods of evaluating the condition of recently captured $N$. norvegicus, such as nucleic acid indices, may therefore provide a valuable tool for the assessment of their nutritional status, and may contribute to stock-management decisions.

Acknowledgements. This work was carried out while P.J.P.W. was in receipt of a Natural Environment Research Council research studentship. We would like to thank the following people for their contributions to this work: Mrs J. Freel for assistance with biochemical analysis, Ms S. Magill for assistance with fieldwork and the crew of the RV 'Aora'. 


\section{LITERATURE CITED}

Aiken DE (1980) Molting and growth. In: Cobb JS, Phillips BF (eds) The biology and management of lobsters, Vol 1. Academic Press, New York, p 2-72

Baden SP, Depledge MH, Hagerman L (1994) Glycogen depletion and altered copper and manganese handling in Nephrops norvegicus following starvation and exposure to hypoxia. Mar Ecol Prog Ser 103:65-72

Bailey N, Chapman CJ (1983) A comparison of the density and length composition and growth of two Nephrops populations off the west coast of Scotland. Int Counc Explor Sea Comm Meet K: 42:1-20

Bailey N, Howard FG, Chapman CJ (1986) Clyde Nephrops: biology and fisheries. In: Allen JA, Barnett PRO, Boyd JM, Kirkwood RC, Mackay DW, Smyth JC (eds) Environment of the Estuary and Firth of Clyde. Proc R Soc Edinb Ser B (Biol Sci) 90:501-518

Buckley LJ (1979) Relationships between RNA-DNA ratio, prey density, and growth rate in Atlantic cod (Gadus morhua) larvae. J Fish Res Board Can 36:1497-1502

Buckley LJ (1984) RNA-DNA ratio: an index of larval fish growth in the sea. Mar Biol 80:291-298

Bulow FJ (1987) RNA-DNA ratio: an index of larval fish growth in the sea. J Fish Res Board Can 27:2343-2347

Burton K (1956) A study of the conditions and mechanisms of the diphenylamine reaction for the colorimetric estimation of deoxyribonucleic acid. Biochem J 62:315-323

Chang ES (1995) Physiological and biochemical changes during the molt cycle in decapod crustaceans: an overview. J Exp Mar Biol Ecol 193:1-14

Chapman CJ (1979) Some observations on populations of Norway lobster, Nephrops norvegicus (L.) using diving, television and photography. Rapp P-V Réun Cons Int Explor Mer 175:127-133

Chapman CJ (1980) Ecology of juvenile and adult Nephrops. In: Cobb JS, Phillips BF (eds) The biology and management of lobsters, Vol 2. Academic Press, London, p 143-178

Chapman CJ, Bailey N (1987) Biological research on fish and shellfish stocks. Recent progress in Norway lobster research. In: Bailey RS, Parish BB (eds) Developments in fisheries research in Scotland. Fishing News Books, Farnham, p 99-111

Chapman CJ, Howard FG (1988) Environmental influences on Norway lobster populations and their implications for fishery management. In: Fincham AA, Rainbow PS (eds) Aspects of decapod crustacean biology. Oxford University Press, Oxford, p 343-353

Clemmesen C (1993) Improvements in the fluorimetric determination of the RNA and DNA content of individual marine fish larvae. Mar Ecol Prog Ser 100:177-183

Clemmesen C (1994) The effect of food availability, age and size on the RNA:DNA ratio of individually measured herring larvae. Mar Biol 118:377-382

Clemmesen C (1996) Does the otolith structure reflect the nutritional condition of a fish larva? Comparison of otolith structure and biochemical index (RNA/DNA ratio) determined on cod larvae. Mar Ecol Prog Ser 138:33-39

Cobb JS, Wahle RA (1994) Early-life history and recruitment processes of clawed lobsters. Crustaceana 67:1-25

Cobb JS, Tamm GR, Wang D (1982) Behavioural mechanisms influencing moult frequency in the American lobster Homarus americanus Milne Edwards. J Exp Mar Biol Ecol 62:185-200

Cole HA (1965) The size distribution of Nephrops populations on grounds around the British coasts. Rapp P-V Réun Cons Perm Int Explor Mer 156:164-171
Cristo M (1998) Feeding ecology of Nephrops norvegicus (Decapoda: Nephropidae). J Nat Hist 32:1493-1498

El Haj AJ, Whiteley NM (1997) Molecular regulation of muscle growth in Crustacea. J Mar Biol Assoc UK 77:95-106

El Haj AJ, Clarke SR, Harrison P, Chang ES (1996) In vivo muscle protein synthesis rates in the American lobster Homarus americanus during the moult cycle and in response to 20-hydroxyecdysone. J Exp Biol 199:579-585

Ferguson M, Danzmann RG (1990) RNA/DNA ratios in white muscle as estimates of growth in rainbow trout held at different temperatures. Can J Zool 68:1494-1498

Field RH, Appleton PL (1995) A Hematodinium-like dinoflagellate of the Norway lobster Nephrops norvegicus observations on pathology and progression of infection. Dis Aquat Org 22:115-128

Field RH, Chapman CJ, Taylor AC, Neil DM, Vickerman K (1992) Infection of the Norway lobster Nephrops norvegicus by a Hematodinium-like species of dinoflagellate on the west coast of Scotland. Dis Aquat Org 13:1-15

Field RH, Appleton PL, Vickerman K, Atkinson RJA, Taylor AC, Rogerson A, Neil DM, Shanks A (1995) Mortality of Nephrops norvegicus on the west coast of Scotland. Report to the Ministry of Agriculture, Fisheries and Food Chief Scientist's Group. Project Ref. CSA2139, University of Glasgow, Glasgow

Field RH, Hills JM, Atkinson RJA, Magill S, Shanks AM (1998) Distribution and seasonal prevalence of Hematodinium sp. infection of the Norway lobster (Nephrops norvegicus) around the west coast of Scotland. ICES J Mar Sci 55:846-858

Foster AR, Houlihan DF, Hall SJ, Burren LJ (1992) The effects of temperature acclimation on protein synthesis rates and nucleic acid content of juvenile cod (Gadus morhua L.). Can J Zool 70:2095-2102

Froglia C, Gramitto ME (1988) An estimate of growth and mortality parameters for Norway lobster (Nephrops norvegicus) in the Central Adriatic Sea. FAO Fish Rep 394:189-203

Goolish EM, Barron MG, Adelman IR (1984) Thermoacclimatory response of nucleic acid and protein content of carp muscle tissue: influence of growth rate and relationship to glycine uptake by scales. Can J Zool 62:2164-2170

Hagerman L (1983) Haemocyanin concentration of juvenile lobsters (Homarus gammarus) in relation to moulting cycle and feeding conditions. Mar Biol 77:11-17

Hagerman L, Baden SP (1988) Nephrops norvegicus: field studies of effects of oxygen deficiency on haemocyanin concentration. J Exp Mar Biol Ecol 116:135-142

Hillis JP (1979) Growth studies on the prawn, Nephrops norvegicus. Rapp P-V Réun Cons Perm Int Explor Mer 175:170-175

Houlihan DF (1991) Protein turnover in ectotherms and its relationship to energetics. In: Gilles R (ed) Advances in comparative and environmental physiology, Vol 7. SpringerVerlag, Heidelberg, p 1-43

Houlihan DF, Kelly K, Boyle PR (1998) Correlates of growth and feeding in laboratory maintained Eledone cirrhosa (Cephalopoda: Octopoda). J Mar Biol Assoc UK 78:919-932

Humphreys CR, Stephenson JR (1973) Changes in epidermal DNA, protein and protein synthesis during the molt cycle of the crayfish Orconectes sanborni (Faxon). Comp Biochem Physiol 44A:1121-1128

IMBC, UMBSM \& IRPEM (1994) Nephrops norvegicus: stock variability and assessment in relation to fishing pressure and environmental factors. Report to the E.C. XIV1MED/91/003. By the Institute of Marine Biology of Crete, University Marine Biological Station, Millport \& Istituto di 
Recerche Sulla Pesca Marittima, IMBC, Crete

Jensen AJC (1965) Nephrops in the Skaggerrak and Kattegat (length, growth, tagging experiments and changes in stock and fishery yield). Rapp P-V Réun Cons Perm Int Explor Mer 156:150-154

Juinio MAR, Cobb JS (1994) Estimation of recent growth of field-caught postlarval American lobsters, Homarus americanus, from RNA:DNA ratios. Can J Fish Aquat Sci 51:286-294

Juinio MAR, Cobb JS, Bengston D, Johnson M (1992) Changes in nucleic acids over the moult cycle in relation to food availability and temperature in Homarus americanus postlarvae. Mar Biol 114:1-10

Kawakami Y, Mochioka N, Kimura R, Nakazono A (1999) Seasonal changes of the RNA/DNA ratio, size and lipid contents and immigration adaptability of Japanese glasseels, Anguilla japonica, collected in northern Kyushu, Japan. J Exp Mar Biol Ecol 238:1-19

Kenchington ELR (1994) Spatial and temporal variation in adductor muscle RNA:DNA ratio in sea scallops (Placopecten magellanicus) in the Bay of Fundy, Canada. J Shellfish Res 13:19-24

Li HW, Brocksen RW (1977) Approaches to the analysis of the energetic costs of interspecific competition for space by rainbow trout (Salmo gairdneri). J Fish Biol 11:329-341

Lodeiros CJM, Fernandez RI, Boumati A, Himmelman JH, Chung KS (1996) Relation of RNA/DNA ratios to growth for the scallop Euvola (Pecten) ziczac in suspended culture. Mar Biol 126:245-251

Lowry OH, Rosenburgh NJ, Farr AL, Randall RJ (1951) Protein measurement with Folin phenol reagent. J Biol Chem 193:265-275

Mejbaum W (1939) Über die Bestimmung kleiner Pentosemengen, insbesondere in Derivaten der Adenylsäure. Z Phys Chem 258:117-120

Miglavs I, Jobling M (1988) Effects of feeding regime on food consumption, growth rates and tissue nucleic acids in juvenile Arctic charr, Salvelinus alpinus, with particular respect to compensatory growth. J Fish Biol 34:947-957

Moss SM (1994a) Use of nucleic acids as indicators of growth in juvenile white shrimp, Penaeus vannamei. Mar Biol 120:359-367

Moss SM (1994b) Growth rates, nucleic acid concentrations, and RNA/DNA ratios of juvenile white shrimp, Penaeus vannamei Boone, fed different algal diets. J Exp Mar Biol Ecol 182:193-204

Mustafa S, Lagardère JP, Pastoureaud A (1991) Condition indices and RNA:DNA ratio in overwintering European sea bass, Dicentrarchus labrax, in salt marshes along the Atlantic coast of France. Aquaculture 96:367-374

Oakley SG (1981) Food, feeding behaviour and some aspects of the biology of Nephrops norvegicus in the Irish Sea. PhD thesis, University of Liverpool

Parslow-Williams, PJ (1998) Nutritional limitation in populations of the Norway lobster, Nephrops norvegicus (L.) in the Firth of Clyde, Scotland. PhD thesis, University of Glasgow

Editorial responsibility: Otto Kinne (Editor),

Oldendorf/Luhe, Germany
Passamonti M, Mantovani B, Scali AV, Froglia C (1997) Allozymic characterization of Scottish and Aegean populations of Nephrops norvegicus. J Mar Biol Assoc UK 77: $727-735$

Pierce GJ, Key LN, Boyle PR, Siegert KJ, Goncalves JM, Porteiro FM, Martins HR (1999) RNA concentration and the RNA to protein ratio in cephalopod tissues: sources of variation and relationship with growth rate. J Exp Mar Biol Ecol 237:185-201

Robbins I, Bergeron JP, Boulhic M, Galois R, Person-Le Ruyet J (1991) Effect of starvation on RNA, DNA and protein content of laboratory-reared larvae and juveniles of Solea solea. Mar Ecol Prog Ser 72:69-77

Sarda F, Valladres FJ (1990) Gastric evacuation of different foods by Nephrops norvegicus (Crustacea: Decapoda) and estimation of soft tissue ingested, maximum food intake and cannibalism in captivity. Mar Biol 104:25-30

Stuck KC, Watts SA, Wang SY (1996) Biochemical responses during starvation and subsequent recovery in postlarval Pacific white shrimp, Penaeus vannamei. Mar Biol 125:33-45

Taylor AC, Field RH, Parslow-Williams PJ (1996) The effects of Hematodinium sp. Infection on aspects of the respiratory physiology of the Norway lobster, Nephrops norvegicus (L.). J Exp Mar Biol Ecol 207:217-228

Thomas HJ (1965) The distribution of the Norway lobster around Scotland and the stock composition in areas of different fishing intensity. Rapp P-V Réun Cons Perm Int Explor Mer 156:176-182

Thomas HJ, Davidson C (1962) The food of the Norway lobster, Nephrops norvegicus (L.). Mar Res Ser Scott Home Dep 3:1-15

Tuck ID (1993) Nephrops abundance in relation to environmental factors and fishing pressure. PhD thesis, University of London

Tuck ID, Chapman CJ, Atkinson RJA (1997a) Population biology of the Norway lobster, Nephrops norvegicus (L.) in the Firth of Clyde, Scotland. I. Growth and density. ICES J Mar Sci 54:125-135

Tuck ID, Chapman CJ, Atkinson RJA, Bailey N, Smith, RSM (1997b) A comparison of methods for stock assessment of the Norway lobster, Nephrops norvegicus, in the Firth of Clyde. Fish Res (Amst) 32:89-100

Tuck ID, Taylor AC, Atkinson RJA, Gramitto ME, Smith C (1997c) Biochemical composition of Nephrops norvegicus: changes associated with ovary maturation. Mar Biol 129: 505-511

Wang SY, Stickle WB (1986) Changes in nucleic acid concentration with starvation in the blue crab Callinectes sapidus Rathbun. J Crustac Biol 6:49-56

Wilder IB, Stanley JG (1983) RNA-DNA ratios as an index to growth in salmonid fishes in the laboratory and in streams contaminated by carbaryl. J Fish Biol 22:165-172

Wright DA, Hetzel EW (1985) Use of the RNA:DNA ratios as an indicator of nutritional stress in the American oyster Crassostrea virginica. Mar Ecol Prog Ser 25:199-206

Submitted: May 8, 2000; Accepted: August 24, 2000

Proofs received from author(s): January 15, 2001 